\title{
Kajian Filosofis berparadigma Positivisme : Pelaksanaan Corporate Social Responsibility sebagai Kewajiban menurut Undang-Undang dalam Mewujudkan Good Corporate Governance
}

\author{
Peni Rinda Listyawati \\ Dosen Fakultas Hukum UNISSULA \\ penirinda@unissula.ac.id
}

\begin{abstract}
Positivism point of view can be declared as valid if it is specified by the institution or the competent authority and based on the rule of higher and not hung on moral values. That legal norm as we know is the Act.

Law is a manifestation of the will of the government or can be said as way to arrange something in order to achieve the objectives as it is mentioned in the political law contained in the preamble or a general description. Furthermore, the Government has enacted the Corporate Law which is found in Article 74. This article set of Social and Environmental Responsibility (Corporate Social Responsibility). The fundamental question is why CSR including ethical conduct/ morality of a company, is included into law which must be implemented by the company? This question can not be answered by jurisprudence that has a limited scope. Since it only study about the norms or rules (laws). Moreover, when this condition occurs, it will go to be the object of philosophical discussion.

Article 74 of Law No. 40 of 2007 has demonstrated that moral action can be increased its power to become law. Social and environmental responsibility norm become a legal obligation. It rules policy to create Acts and give sanction. The basic value is that the company in business activity has caused negative impacts resulting in losses for the community. In addition, CSR is responsible on the principle of sustainable development. Thereby, by implementing Corporate Social Responsibility properly, it will create Good Corporate Governance (GCG)
\end{abstract}

Keywords: positivism paradigmf, philosophy, corporate social resposibility, good corporate governance

\begin{abstract}
Abstrak
Intisari aliran positivisme adalah bahwa norma hukum dinyatakan sah apabila ditetapkan oleh lembaga atau otoritas yang berwenang dan didasarkan pada aturan yang lebih tinggi, bukan digantungkan pada nilai moral. Norma hukum yang ditetapkan itu tidak lain adalah Undang-Undang.

Undang-undang merupakan perwujudan atau kehendak pemerintah untuk mengatur sesuatu guna mencapai tujuan yang hendak dicapai sebagai mana tercermin dalam politik hukumnya yang terdapat dalam konsideran atau penjelasan umum. Berkaitan dengan hal itu, maka pemerintah telah mengesahkan Undang-Undang Perseroan Terbatas yang dalam Pasal 74-nya mengatur tentang Tanggung Jawab Sosial dan Lingkungan (Corporate Social Responsibility). Pertanyaan mendasar mengapa CSR yang termasuk tindakan etis/moral dari suatu perusahaan, dinormakan menjadi undang-undang yang wajib dilaksanakan oleh perusahaan? Pertanyaan semacam ini tidak dapat dijawab oleh ilmu hukum yang mempunyai ruang lingkup yang terbatas, karena hanya mempelajari tentang norma atau aturan (hukum). Manakala persoalan-persoalan mendasar tidak bisa dijawab oleh ilmu hukum, maka akan menjadi obyek bahasan filsafat.
\end{abstract}


Pasal 74 UU No. 40 Tahun 2007 ini telah memperlihatkan bahwa tindakan moral dapat ditingkatkan daya berlakunya menjadi hukum. Penormaan tanggung jawab sosial dan lingkungan menjadi kewajiban hukum merupakan kebijakan hukum pembentuk undang-undang untuk mengatur dan menerapkan tanggung jawab sosial dan lingkungan dengan suatu sanksi. Landasan filosofisnya bahwa perseroan dalam melakukan aktivitas bisnis telah menimbulkan dampakdampak negatif yang mengakibatkan kerugian bagi masyarakat, selain itu yang melatarbelakangi CSR menjadi wajib adalah berdasarkan prinsip pembangunan berkelanjutan. Dengan demikian melaksanakan Corporate Social Responsibility dengan baik maka akan terwujud Tata Kelola Perusahaan yang baik (Good Corporate Governance).

Kata kunci: Paradigma Positivisme, Filosofis, Corporate Social Resposibility, Good Corporate Governance

\section{A. Pendahuluan}

Paradigma Positivisme Hukum memandang Undang-Undang atau keseluruhan peraturan sebagai sesuatu yang memuat hukum secara lengkap. Menurut tokoh Positivisme John Austin, hukum adalah perintah dari penguasa yang memegang kekuasaan tertinggi dan berdaulat. ${ }^{1}$ Aturan-aturan hukum yang dibuat dan diberlakukan di masyarakat adalah aturan yang tertulis sebagai perwujudan kehendak dan keinginan pemerintah.

Hukum dari segi sifatnya dikonsepkan sebagai suatu sistem yang bersifat logis, tetap dan tertutup, artinya memisahkan hukum dan moral (keadilan). Sedangkan menurut Hans Kelsen dengan Aliran Hukum Murninya menyatakan bahwa konsep penerapan hukum harus dengan pendekatan metode normatif yuridis yang bersih dari anasir non-yuris, seperti sosial, ekonomi, sosial, sejarah dan etika. Dengan demikian peraturan hukum selalu merupakan hukum positif. Konsep hukum positif

adalah hukum dalam kenyataan, dan yang dipersoalkan oleh hukum bukan bagaimana hukum itu seharusnya tetapi apa hukumnya. ${ }^{2}$

Sedangkan menurut Aliran Filsafat Hukum Legal Positivisme, hukum dimaknai sebagai law as what it is written in the books. Aliran ini memahami hukum sebagai ius constitutum, yaitu hukum yang ada dan berlaku. Hukum sebagai

1 Muhammad Erwin, 2012, Filsafat Hukum Refleksi Kritis terhadap Hukum, Raja Grafindo Persada, Jakarta, hlm. 157-158.

2 Abdul Ghofur Anshori, 2009, Filsafat Hukum, Gadjah Mada University Press, Yogyakarta, hlm. 98-99. produk eksplisit suatu sumber kekuasaan politik tertentu yang berlegitimasi. Dalam hal ini hukum terwujud sebagai perintah-perintah eksplisit yang secara positif telah terumus jelas guna menjamin kepastian, misal peraturan perundang-undangan yang berlaku secara nasional di suatu negara. ${ }^{3}$

Peraturan perundang-undangan yang sedang berlaku di suatu negara disebut hukum positif, contohnya Undang-Undang Nomor 40 Tahun 2007 tentang Perseroan Terbatas yang dalam Pasal 74 mengatur tentang Tanggung Jawab Sosial dan Lingkungan (Corporate Social Responsibility). Pertanyaan yang muncul apa yang dimaksud tanggung jawab sosial itu, dan mengapa perusahaan harus mempunyai tanggung jawab sosial dan lingkungan. Jawaban atas pertanyaan tersebut tidak dapat dijawab dengan norma atau aturan hukum (hukum positif). Manakala persoalan-persoalan mendasar yang berkenaan dengan hukum tidak dapat dijawab lagi oleh ilmu hukum, maka hal tersebut menjadi obyek bahasan ilmu filsafat. Mengapa? karena filsafat memiliki obyek bahasan yang sangat luas yang dapat dijangkau oleh pikiran manusia yang berusaha menelusurinya jauh di balik apa yang tampak dengan maksud menentukan sesuatu yang disebut dengan nilai.

Nilai dalam pengertian ini adalah suatu kualitas abstrak yang ada pada sesuatu hal. Nilai tidak dapat dilihat sebagai sesuatu yang konkrit tetapi nilai dapat dimengerti dan dihayati. Dengan demikian, dapat dikatakan bahwa yang dimaksudkan dengan nilai adalah suatu kualitas

3 Erlyn Indarti, Diskresi dan Paradigma, dalam pidato pengukuhan Guru Besar, hlm. 21. 
abstrak yang dapat menimbulkan rasa senang, puas atau bahagia bagi orang yang mengalami dan menghayatinya. ${ }^{4}$ Apabila dikaitkan dengan peraturan atau undang-undang, maka undangundang itu harus bisa membahagiakan, memberi rasa adil, kepastian, dan kemanfaatan bagi masyarakat.

Apabila dikaitkan dengan CSR yang awalnya sebagai kegiatan charity, CSR di Indonesia telah diatur dalam Undang-Undang Perseroan Terbatas sebagai kewajiban yang harus dilakukan perusahaan. Dengan demikian Undang-Undang Perseroan Terbatas ini merupakan hukum positif yang berlaku di Indonesia. Berbicara hukum positif yang merupakan hukum dalam kenyataan, maka yang dipersoalkan oleh hukum bukan bagaimana hukum itu seharusnya, tetapi apa hukumnya. Sedangkan menurut tokoh Positivisme John Austin, hukum adalah perintah dari penguasa yang memegang kekuasaan tertinggi dan berdaulat. Aturan-aturan hukum yang dibuat dan diberlakukan di masyarakat adalah aturan yang tertulis sebagai perwujudan kehendak dan keinginan pemerintah. Dengan demikian Undang-undang Perseroan Terbatas (UU No. 40 Tahun 2007) adalah perwujudan dan kehendak pemerintah yang berlaku di wilayah Indonesia, untuk rakyat (pengusaha) Indonesia yang harus dilaksanakan/ditaati. Di satu sisi pertanyaan mendasar mengapa CSR yang

termasuk tindakan etis/moral dari suatu perusahaan dinormakan menjadi undang-undang yang wajib dilaksanakan oleh perusahaan akan menjadi kajian filsafat.

Berdasarkan pemahaman paradigma positivisme hukum tersebut, penulis mencoba mengkaji realitas Pasal 74 Undang-Undang Perseroan Terbatas yaitu mengkaji Pelaksanaan Corporate Social Responsibility sebagai kewajiban menurut Undang-Undang dalam Mewujudkan Good Corporate Governance dari kajian filosofi berparadigma positivisme hukum.

\section{B. Permasalahan}

Berdasarkan uraian di atas, permasalahan yang akan diketengahkan adalah:

1. Apa yang menjadi dasar filosofis pelaksanaan Corporate Social

4 Muhammad Erwin, Op. Cit., hlm. 20.
Responsibility diwajibkan menurut undang-undang?

2. Apakah pelaksanaan Corporate Social Responsibility dapat mendorong terwujudnya Good Corporate Governance?

\section{Pembahasan}

\section{Dasar Filosofis Pelaksanaan Corporate Social Responsibility yang Diwajibkan menurut Undang-Undang.}

Berbicara tentang filsafat tidak dapat dilepaskan dari 3 (tiga) aspek utama, yaitu ontologi, epistemplogi, dan aksiologi. Ontologi yang merupakan cabang ilmu utama dari filsafat, membahas tentang hakikat mendasar atas keberadaan sesuatu. Berbicara tentang hakikat tidak lain bicara tentang intisari, dasar atau kenyataan yang sebenarnya. Hakikat sesuatu adalah keadaan sebenarnya dari sesuatu. Kegiatan mencari hakikat ini adalah kegiatan berfilsafat, yaitu berpikir dalam tahap makna, ia mencari dan menemukan hakikat makna terdalam dari sesuatu, ia mencari dan menemukan jawaban di balik sesuatu yang disebut nilai dari sebuah realitas. ${ }^{5}$ Ontologi berusaha mencari inti yang termuat di dalam setiap kenyataan atau penjelasan yang ada dalam setiap bentuknya. Sedangkan epistemologi membahas pengetahuan yang diperoleh manusia, atau membahas tentang metode. Selanjutnya istilah aksiologi dapat diartikan sebagai teori nilai yang berkaitan dengan kegunaan atau tujuan dari obyek yang dikaji.

Berdasarkan hal tersebut, maka konsep CSR yang di Undang- Undang Perseroaan Terbatas dikenal dengan istilah tanggung jawab sosial dan lingkungan (TJSL) ini pada hakikatnya (ontologi) sesuai dengan nilai-nilai yang terkandung dalam Pancasila khususnya sila ke-5 yaitu "Keadilan sosial bagi seluruh rakyat Indonesia". Nilai-nilai dalam Pancasila ini lebih lanjut dijabarkan dalam UndangUndang Dasar Republik Indonesia Tahun 1945 dalam Bab XIV tentang Perekonomian Nasional dan Kesejahteraan Sosial. Dalam Pasal 33 UUD 1945 hasil amandemen ini menjadi dasar pengaturan lebih lanjut dalam

5 Abdul Ghofur Anshori, Op.Cit., hlm. 2. 
hal pengelolaan perekonomian nasional dan perwujudan kesejahteraan sosial. Ketentuan inilah yang manjadi dasar rujukan dalam pembuatan kebijakan ekonomi. Kebijakan ekonomi ini dapat kita lihat dengan lahirnya Undang-undang Perseroan Terbatas, UndangUndang Penanaman Modal, dan UndangUndang Lingkungan. Dengan demikian undang-undang tersebut dibuat ontologinya untuk mensejahterakan masyarakat Indonesia.

Berpijak dari kebijakan ekonomi dengan lahirnya undang-undang mengenai perekonomian, menarik untuk dikaji UndangUndang Perseroan Terbatas yang dalam Pasal 74-nya mengatur tentang Tanggung Jawab Sosial dan Lingkungan (TJSL) atau lebih dikenal dengan Corporate Social Responsibility (CSR).

Corporate Social Responsibility (Tanggung Jawab Sosial Perusahaan) diatur secara tegas dalam Undang-Undang No. 40 Tahun 2007 tentang Perseroaan Terbatas dan Undang-Undang No. 25 Tahun 2007 tentang Penanaman Modal. Pasal 74 ayat (1) UU No. 40 Tahun 2007 berbunyi: "Perusahaan yang menjalankan kegiatan usahanya di bidang dan/atau berkaitan dengan sumber daya alam wajib melaksanakan tanggung jawab sosial dan lingkungan". Mencermati bunyi pasal tersebut, tertulis bahwa pelaksanaan Corporate Social Responsibility adalah sebuah kewajiban (mandatory) bagi perusahaan.

Sedangkan dalam Pasal 15 UndangUndang No. 25 Tahun 2007 tentang Penanaman Modal berbunyi: "Setiap penanam modal berkewajiban menerapkan prinsip tata kelola perusahaan yang baik dan melaksanakan tanggung jawab sosial perusahaan, membuat laporan tentang kegiatan penanaman modal dan menyampaikannya kepada Badan Koordinasi Penanaman Modal, menghormati tradisi budaya masyarakat sekitar lokasi kegiatan usaha penanaman modal, dan mematuhi semua ketentuan peraturan perundang-undangan."

Sedangkan Pasal 34 ayat (1) UU No. 25 Tahun 2007 berbunyi: "Badan usaha atau usaha perseorangan sebagaimana dimaksud dalam Pasal 5 yang tidak memenuhi kewajiban sebagaimana ditentukan dalam Pasal 15 dapat dikenai sanksi administratif berupa :

a. peringatan tertulis

b. pembatasan kegiatan usaha

c. pembekuan kegiatan usaha dan /atau fasilitas penanaman modal;

d. pencabutan kegiatan usaha dan/atau fasilitas penanaman modal.

Mencermati ketentuan Pasal 74 UU No. 40 Tahun 2007 tentang Perseroan Terbatas dan Pasal 15 UU No. 25 Tahun 2007 tentang Penanaman Modal telah mengatur CSR sebagai kewajiban yang harus dijalankan oleh perusahaan, dan bagi yang tidak memenuhi kewajiban akan dikenai sanksi merupakan ciri ajaran positivisme. Ajaran positivisme ini memaknai hukum sebagai Ius Constitutum, yaitu "hukum yang ada dan berlaku saat ini". Dengan kata lain UU No. 40 Tahun 2007 dan UU No. 25 Tahun 2007 merupakan lus Constitutum, yang terbit sebagai produk eksplisit dari kekuasaan politik yang berlegitimasi. Hukum terwujud sebagai perintah-perintah eksplisit yang secara positif terumus dengan jelas dan bersanksi guna menjamin kepastiannya.

Pertanyaan yang muncul kemudian adalah apa dasar filosofisnya CSR yang termasuk tindakan etis/moral dari suatu perusahaan, dinormakan menjadi undangundang yang wajib dilaksanakan oleh perusahaan? Hal ini dapat ditelaah bahwa keberadaan industri apapun bentuknya selalu menimbulkan dampak. Dampak yang timbul dapat digolongkan menjadi 2 (dua), yaitu dampak negatif dan dampak positif. Dampak positif antara lain tersedianya lapangan kerja, peningkatan pendapatan msyarakat, pemukiman baru, dan lain-lain. Dampak negatif selalu timbul yang berakibat terganggunya lingkungan hidup masyarakat, antara lain polusi udara, pencemaran air, kebisingan lingkungan, dan lain-lain.

Dampak negatif ini harus dikurangi dengan cara melakukan mitigasi (usaha untuk mengurangi akibat dampak negatif). Mitigasi dapat digolongkan menjadi mitigasi secara fisik dan mitigasi sosial. Mitigasi secara sosial dengan melaksanakan Corporate 
Social Responsibility. ${ }^{6}$

Berpijak dari realitas dampak tersebut, maka DPR dan pemerintah bersikeras agar CSR harus tetap menjadi kewajiban perseroan. Sedangkan pijakan filisofisnya bahwa pada hakikatnya CSR adalah nilai atau jiwa yang melandasi aktivitas perusahaan secara umum, dikarenakan CSR menjadi pijakan komprehensif dalam aspek ekonomi, sosial, kesejahteraan dan lingkungan. Regulasi CSR dalam UndangUndang Perseroan Terbatas dilandasi folosofi menciptakan jalinan hubungan koorporasi yang seimbang, serasi, dan selaras dengan lingkungan nilai, norma, serta budaya masyarakat setempat. Dengan demikian perusahaan tidak hanya mengeksploitasi sumber daya alam secara besar-besaran demi mengejar keuntungan ekonomi saja, tetapi juga harus memperhatikan tanggungjawab sosialnya.

Dengan demikian hakikat CSR adalah nilai yang melandasi aktivitas perusahaan, yaitu nilai keseimbangan, kewajiban, kejujuran dan komitmen. Nilai keseimbangan menunjukkan kegiatan CSR sesungguhnya adalah melindungi lingkungan alam dan melindungi keberlangsungan hidup komunitas sosialnya dari dampak negatif yang ditimbulkan oleh aktivitas operasional perusahaan. Apabila aktifitas operasional perusahaan menimbulkan dampak negatif, maka kewajiban perusahaan harus memberikan keseimbangan terhadap dampak yang ditimbulkan kepada lingkungan dan masyarakat, yaitu dengan cara preventif (menyiapkan/membangun pembuangan limbah dengan mengacu pada peraturan yang berlaku) dan memperbaiki lingkungan yang rusak serta menyeimbangankan kelangsungan hidup masyarakat sekitar perusahaan. Ironis apabila suatu daerah berdiri perusahaan besar yang produksinya dinikmati masyarakat dunia, namun masyarakat sekitar perusahaan dalam keadaan miskin dan hidup dalam lingkungan yang tidak layak (masyarakat menikmati polusi yang dihasilkan pabrik, baik polusi udara, air, dan jalan-jalan yang

$6 \quad$ Sukandarrumidi, 2012, Corporate Social Responsibility, Bajawa Press, Yogyakarta, hlm. 30. rusak karena dampak dari transportasi bahanbahan produksi pabrik dan sebagainya).

Nilai kejujuran yang dibangun sebagai visi-misi perusahaan merupakan komitmen yang harus dikonkritkan dalam aktivitas perusahaan. Jujur atas bahan-bahan produk yang aman dikomsumsi konsumen, jujur terhadap rekanan, karyawan dan pelanggan. Dengan kata lain nilai jujur yang menjadi visimisi sebuah perusahaan kepada shareholder dan stakeholder, menunjukkan perilaku etis dari sebuah perusahaan.

Hakikat CSR memberi perlindungan dalam artian perusahaan berkewajiban untuk melindungi lingkungan alam dari kerusakan serta melindungi keberlangsungan hidup komunitas sosialnya dari dampak negatif yang ditimbulkan dari aktivitas operasional perusahaan. Dengan adanya kewajiban perusahaan untuk melindungi atas dampak yang ditimbulkan, maka kegiatan CSR bukan lagi sekedar kegiatan amal sosial atau seremonial perusahaan yang bersifat kontemporer dan sukarela atau kedermawanan perusahaan yang lebih cenderung bersifat belas kasihan perusahaan terhadap komunitas sosialnya dan lingkungan alamnya. Dengan demikian hakikat CSR adalah "berbagi dengan ikhlas untuk kemaslahatan umat manusia dan lingkungan alamnya"

Dengan demikian melaksanakan CSR dengan sesuai hakikatnya maka akan tercapai aksiologi CSR yaitu menseimbangkan kemaslahatan antara manusia dan alam dan memberikan kesejahteraan bagi masyarakat luas.

\section{Pelaksanaan Corporate Social Responsibility dapat mendorong terwujudnya Good Corporate Governance}

Di era globalisasi dan pasar bebas, negaranegara di dunia dituntut untuk menerapkan paradigma baru dalam pengelolaan bisnis, yaitu pengelolaan bisnis yang berbasis prinsipprinsip tata kelola perusahaan yang baik (Good Corporate Governance). Isu-isu yang terkait dengan Corporate Governance ini adalah insider trading, transparansi, akuntabilitas, 
independensi, tanggung jawab sosial perusahaan (Corporate Social Responsibility). Dengan demikian Good Corporate Governance dan Corporate Social Responsibility merupakan kebutuhan perusahaan untuk tetap bisa eksis dan "bermain" di pasar bebas. Perkembangan ekonomi dan perdagangan dunia semakin kompetitif sehingga perlu diupayakan langkahlangkah untuk meningkatkan efisiensi dan daya saing serta pengembangan budaya dan pengaturan perusahaan yang antisipasif terhadap perkembangan lingkungan strategi dalam dan luar negeri.

Berdasarkan ketentuan perdagangan dunia mensyaratkan GCG dan CSR bagi perusahaan yang ingin eksis di dunia perdagangan dunia, maka Indonesia merespon dengan mengamandemen UndangUndang Perseroaan Terbatas, yaitu dengan mengatur CSR sebagai suatu kewajiban bagi perusahaan yang diatur dalam Pasal 74 UU No. 40 Tahun 2007. Sedangkan Good Corporate Governance diatur dalam Undangundang Penanaman Modal, Keputusan Menteri Badan Usaha Milik Negara No: Kep-117/M-MBU/2002 tentang Penerapan Praktek Good Corporate Governance dalam Badan Usaha Milik Negara (BUMN). Implementasi Good Corporate Governance (GCG) dapat dilaksanakan dengan berhasil apabila memiliki beberapa prinsip, yaitu: ${ }^{7}$

a. Transparasi (Transparency), artinya untuk menjaga obyektivitas dalam menjalankan bisnis, perusahaan harus menyediakan informasi yang relevan dengan cara yang mudah diakses dan mudah dipahami oleh pihak yang berkepentingan.

b. Akuntabilitas (accountability), artinya perusahaan harus dapat mempertanggungjawabkan kinerjanya secara transparan dan wajar, untuk itu perusahaan harus dikelola secara benar dan terukur, dengan tetap memperhatikan kepentingan pemegang saham. Akuntabilitas ini merupakan prasyarat untuk mencapai kinerja yang berkesinambungan.

7 Ismail Solihin, 2011, Corporate Social Responsibility, Salemba Empat, Jakarta, hlm. 125-126. c. Responsibilitas (responsibility), artinya perusahaan harus mematuhi peraturan perundang-undangan dan melaksanakan tanggung jawab terhadap masyarakat dan lingkungan sehingga terpelihara kesinambungan usaha dalam jangka panjang.

d. Independensi (independency), artinya perusahaan harus dikelola secara independen sehingga masingmasing organ perusahaan tidak saling mendominasi dan tidak dapat diintervensi oleh pihak lain.

e. Kewajaran dan kesetaraan (fairness), artinya perusahaan harus senantiasa memperhatikan kepentingan pemegang saham dan pemangku kepentingan lainnya.

Mencermati prinsip-prinsip Good Corporate Governance tersebut di atas, memperlihatkan bahwa telah terjadi perubahan paradigma di dunia perdagangan (perusahaan), yang tadinya sistemnya tertutup artinya hanya berpikir untuk kepentingan perusahaan saja, sekarang perubahan paradigma menjadi sistem terbuka, artinya selain memperhatikan kepentingan perusahaan (internal) juga harus memperhatikan kepentingan stakeholder (eksternal). Hal ini terlihat dalam prinsip akuntabilitas dan prinsip responsibility.

Dengan demikian sebelum perusahaan melaksanakan aktivitas Corporate Social Responsibility (CSR), perusahaan harus lebih dahulu membenahi kepatuhan perusahaan terhadap hukum, menjalankan bisnisnya dengan baik dan juga perlu mengembangkan sejumlah kebijakan untuk menuntun pelaksanaan CSR. Hal ini tidak akan terlaksana dengan baik apabila perusahaan tidak menerapkan Good Corporate Governance (GCG) dengan baik.

Selain itu, pelaksanaan CSR juga menjadi salah satu prinsip pelaksanaan GCG (yaitu prinsip responsibilitas). Dengan demikian perusahaan yang melaksanakan GCG seharusnya sudah melaksanakan CSR, sekaligus terjawab bahwa pelaksanaan CSR dapat mendorong terwujudnya GCG.

Mencermati realitas CSR dan GCG 
sebagaimana yang diuraikan di atas, terlihat bahwa pengusaha/korporasi menjalankan hanya sekedar menjalankan bunyi undangundang. Dalam ketentuan SK Menteri BUMN No. Kep-117/M-MBU/2002 dinyatakan bahwa sumber pendanaan dari pelaksanaan CSR berasal dari laba perusahaan. Konsekuensi dari ketentuan tersebut apabila perusahaan itu tidak untung/laba, maka perusahaan tersebut tidak melaksanakan CSR, atau apabila melaksanakan CSR sekedar membantu/ derma sekedarnya, misalnya membantu nasi bungkus untuk korban banjir. Padahal yang dimaksud CSR tidak sekedar derma, tetapi konsep CSR dapat dijadikan salah satu strategi oleh perusahaan untuk meningkatkan citra perusahaan yang akan turut mempengaruhi kinerja keuangan perusahaan serta dalam kerangka sustainable development .

Dengan demikian para pengusaha/ korporasi cara berhukumnya memakai paradigma positivisme, sekedar mematuhi bunyi undang-undang, tidak dimaknai nilai-nilai apa dibalik bunyi undang-undang/ peraturan tersebut.

\section{Penutup}

\section{Kesimpulan}

a. Dasar Filosofis Pelaksanaan Corporate Social Responsibility yang Diwajibkan menurut Undang-Undang.

Regulasi CSR dalam UndangUndang Perseroan Terbatas dilandasi folosofi menciptakan jalinan hubungan koorporasi yang seimbang, serasi, dan selaras dengan lingkungan nilai, norma, serta budaya masyarakat setempat. Dengan demikian perusahaan tidak hanya mengeksploitasi sumber daya alam secara besar-besaran demi mengejar keuntungan ekonomi saja, tetapi juga harus memperhatikan tanggungjawab sosialnya.

Dengan demikian hakikat CSR adalah nilai yang melandasi aktivitas perusahaan, yaitu nilai keseimbangan, kewajiban, kejujuran dan komitmen. b. Pelaksanaan Corporate Social Responsibility dapat mendorong terwujudnya Good Corporate Governance.

Implementasi Good Corporate Governance (GCG) dapat dilaksanakan dengan berhasil apabila memiliki beberapa prinsip, yaitu: transparansi, akuntabilitas, responsibilitas, independensi, kewajaran dan kesetaraan. Dengan demikian pelaksanaan CSR menjadi salah satu prinsip pelaksanaan GCG (yaitu prinsip responsibilitas). Dengan demikian perusahaan yang melaksanakan GCG seharusnya sudah melaksanakan CSR, sekaligus terjawab bahwa pelaksanaan CSR dapat mendorong terwujudnya GCG.

2. Saran

a. Seyogyanya daerah yang belum membuat Perda CSR, segera membuat agar perusahaan mempunyai pemahaman yang sama tentang konsep CSR, dan dalam tingkat daerah atau propinsi segera dibentuk forumforum CSR agar perusahaan memperoleh pemahaman, pengalaman, pembelajaran, dan cara pelaksanaan CSR yang mempunyai nilai tambah bagi perusahaan dan mempunyai nilai kemaslahatan bagi masyarakat dan lingkungan.

b. Bagi perusahaan seharusnya mematuhi peraturan perundangundangan yang terkait dengan CSR sehingga dapat terpelihara kesinambungan usaha dalam jangka panjang dan mendapat pengakuan sebagai Good Corporate Governance. 


\section{DAFTAR PUSTAKA}

Abdul Ghofur Anshori, 2009, Filsafat Hukum, Gadjah Mada University Press, Yogyakarta.

Andreas Lako, 2011, Dekonstruksi Corporate Paradigma Bisnis \& Akutansi, Erlangga, Jakarta. Erlyn Indarti, 2010, Diskresi dan Paradigma, Pidato Pengukuhan Guru Besar, Undip, Semarang. Hendrik Budi Untung, 2008, Corporate Social Responsibility, Sinar Grafika, Jakarta.

Ismail Solihin, 2011, Corporate Social Responsibility, Salemba Empat, Jakarta.

Joni Emirzon, 2007, Prinsip-Prinsip Good Corporate Governance, Genta Press, Yogyakarta.

Muhamad Erwin, 2012, Filsafat Hukum Refleksi Kritis terhadap Hukum, Raja Grafindo Persada, Jakarta.

Sukandarrumidi, 2012, Corporate Social Responsibility, Bajawa Press, Yogyakarta.

Widodo Dwi Putro, 2011, Kritik Terhadap Paradigma Positivisme Hukum, Genta Publishing, Yogyakarta.

Undang-Undang Nomor 40 Tahun 2007 tentang Perseroaan Terbatas.

Undang-Undang Nomor 25 Tahun 2007 tentang Penanaman Modal 